zie den datum 3 Mei in le aanteekening $\mathrm{E} 4$ a 1 van het tweede voorbecld.

Achter de dubbele verticale lijn volgt weder een smal kolommetje, hetwelk dient voor het plaatsen van een contrôle-teeken. De beteekenis daarvan hopen wij te bespreken in een artikel omtrent de "C'ontrôleteekens".

De twee andere kolommen, rechts van de dubbele verticale lijn, dienen resp. om aan to teekenen op welke wijze de gemaakte notitie is afgehandeld, zooals hiervoor reeds gezegd, en voor de paraaf van den leider der desbetreffende controle, waarop wij in een volgend artikel hopen terug te komen.

Nog dient in dit verband er op gewezen, dat het noodig is. opdat het maken van aanteekeningen van de soort, als hiervoor besproken, een doeltreffend middel zijn kan om te geraken tot de doeleinden, in den aanvang van dit artikel omschreven, den assistenten te instrueeren, alle opmerkingen omtrent geboekte posten of geconstateerde verschillen onmiddellijk op het daarvoor bestemde formulier aan te teekenen, ook al is van eene foutieve boeking, direct na het constateeren der fout, de herstelpost aan den boekhouder opgegeven. Tevens moet bij alle aanteckeningen worden vermeld, of en zoo ja, op welke wijze de controleul de vorschillen heeft doen herstellen resp. of het verschil dan wel de kwestie, welke aanleiding tot eene opmerking gaf, met den cliënt of diens personeel is besproken en wat hun antwoord was.

Het op de voorbeelden ingevulde Dossiernummer 72214 beteekent, dat het dossier betrekking heeft op

cliënt No. 214 inzake

de controle over 1.927 ,

terwijl met de 2 achter het cijfer 7 bedoeld is, dat

het een cliënt is van het kantoor Amsterdam b.v.

Zou voor cliënten van het kantoor Utrecht eene 3 als aanduidingseijfer zijn vastgesteld, dan moet op het dossier, de mappen en formulieren van eliënt No. 61 van dat kantoor, betrekking hebbende op de contrôle over 1928 derhalve vermeld worden als Dossiernummer 83061.

Met ,cliënt" wordt uiteraard niet altijd de opdrachtgever bedoeld, doch in het algemeen de persoon of het lichaam, wiens administratie gecontroleerd wordt.

Wij zullen op dit onderdecl echter niet verder ingaan, aangezien zulks ons zou voeren op het terrein del. ,Organisatic van het Accomntantskantool", wat niet de bedocling van dit artikel is.

Ofschoon ,aanteckenen" en ,vastleggen" hier in wezen svnoniem zijn, hebben wij tusschen die twee toch een onderscheid gemaakt, omdat ook de practijk een onderscheid kent. Met het laatstgenoemde wordt dan bedoeld, het vastleggen in het dossier van gecontrolecrde cijfers, een systeem van aantcekenen, dat ook onder den naam van ,,doubleeren" bekend is.

Wij stellen ons roor dit onderdeel in een vervolg-artikel te behandelen.

\section{G. HARTOG}

\section{EFFICIËNTIE.}

\section{Red.: L. POLAK}

(Bijdragen en mededeelingen zende men aan den Secretaris der Redactie)

\section{Welke bezuiniging wordt bij de invoering van boekhoud- machines verkregen?}

Reeds herhaaldelijk hebben wij erop gewezen, dat bij mechanisatie van boekhoudingen slechts in een zeer beperkt aantal

gevallen op werkelijk verkregen bezuiniging door de machines, kan worden gewezen, maar dat vrijwel steeds de bezuiniging wordt verkregen door de eenvoudiger organisatie. Het deed ons genoegen in een Amerikaansch tijdschrift, de driemaandelijksche publicatie van Harward University, cen beschouwing te lezen van de hand van twee medewerkers die als uitslag gegeven wordt van een door hen ingesteld onderzoek. waarin vrijwel een zelfde meening als reeds herhaaldelijk door ons werd gegeven, wordt aangetroffen.

Wij laten hier een uittreksel van het desbetreffende artike] volgen :

\title{
BEZUINIGING EN EFFICIENCY BIJ HET GEBRUIK VAN BOEKHOUDMACHINES
}

,Het constateeren van bezuinigingen door invoering van kantoormachines is moeilijk daar:

1c. de meeste ondernemingen wel hun totale kantooronkosten kennen, maar niet de kosten van de verschillende soorten kantoorarbeid.

2e. bij de invoering van machines worden niet dezelfde gegevens verstrekt als vrocger.

\section{KOSTEN VAN BOEKEN MET MACHINES}

On de kosten met een bepaalde machine te berekenen moet men het gemiddelde loon weten van den persoon die de machine bodient en het werk dat met do machine wordt verkregen.

De gemiddelde productiviteit van de machine - bedoeld wordt hier natumlijk Hollerith-en Powers-machine - blijkt uit een dergelijk staatje:

\section{Werkzaambeden}

vertical sorteeren horizontaal sorteeren optellen

$$
\begin{gathered}
\text { geschat aantal } \\
\text { kaarten per uur } \\
15.000 \\
24.000 \\
9.000
\end{gathered}
$$

Wanneer er op 45 kolommen gepunched wordt, kunnen per uur per persoon 360 à 400 kaarten gepunched worden. Bịj een minder aantal kolommen kan dat aantal grooter zijn.

Eén bediende is er noodig om de totalen van de automatische telmachine op te teekenen en de machine na het nitgooien van de totalen te laten stoppen. Een bediende kan werken hetzij aan 2 sorteerders, hetrij an 2 of 3 schrijvende telmachines, hetzij aan één sorteerdel en één schrijvende telmachine.

Hieronder een schatting van de kosten aan deze werkzaamheden verbonden:

xxx.xxx kaarten per maand à $\$ \mathrm{x} . \mathrm{xx}$ per 1000

Punchen :

xxx.xxx krt. à 350 per uur $=\operatorname{xxxx}$ uren à $\mathrm{xx}$ et. per uur

voor loon

$\operatorname{xxx} . \mathrm{Xx}$

Afwerken :

$\mathrm{xxx}$ uren (coding) à $\mathrm{xx}$ cents per uur ..................... \$ $\mathrm{xx.xx}$

$\mathrm{xxx}$ uren optellen $\mathrm{a} \mathrm{xx}$ cents per uur .........................., "xx.xx xxx uren controleeren à $\mathrm{xx}$ cents per uur , $\mathrm{xx} \cdot \mathrm{xx}$

$"$ $\mathrm{xx} . \mathrm{xx}$

Bediening Machine:

xxx.xxx kit. gezet op 15 soorten is x.xxx.xxx krt. à 11.000 per uur (of 20.000 ) is $\mathrm{xxx}$ uren op sorteerder ả $\mathrm{xx}$ cents

$\operatorname{xxx} \cdot \mathrm{xx}$
11.000

0.000

6.000 


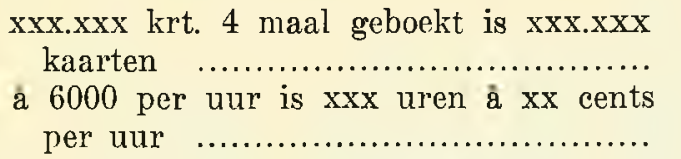

xxx uren voor de bediening â $x x$ cents ...

Waardevermindering en onderhoud kantoormeubelen

Stilstand

Diverse kosten

Totale kosten per maand

\section{KOSTEN VAN DE BOEKHOUD-AFDEELING}

Om de kosten van de boekhouding te kunnen vergelijken met die van machinalen arbeid, moet men weten hoeveel arbeid es noodig is voor een bepaald werk, b.v. het opmaken van de loonlijst, de verdeeling van de loonlijst, het opmaken van materiaal-verbruik, enz.

Bij deze arbeidskosten komen de aanschaffingskosten van de diverse kantoormachines.

\section{VERGELIJKING VAN DE RESULTATEN}

Bij vergelijking van de kosten van handen-arbeid met machinalen arbeid, moeten de kosten van dezelfde bewerkingen worden opgemaakt. Hierin schuilt de moeilijkheid omdat de meest efficiënte werkwijze voor machines niet altijd de meest effi ciënte werkwijze voor handen-arbeid is.

De machinale en hand-administratie geven dan ook andere uitkomsten; b.v. ook door het snellere werken van de machines.

Dientengcvolge moet men er altijd rekening mee houden, dat, al zijn de kosten van machinalen arbeid hooger, hiertegenover andere voordeelen als grootere snelheid, grooter accuratesse, uitgebreider gegevens enz. staan.

\section{ANALYSE VAN DE KOSTEN VAN BOEKHOUD- MACHINES}

Het gebruiken van een gepunchte kaart voor één doel heeft geen nut: Een telmachine kan de bedragen sneller tellen, dan dat de kaarten eerst gepuncht worden en daarna door de boekhoudmachine gaan. De voordeelen van deze machine nemen toe naarmate het aantal keeren dat een kaart gebruikt wordt. grooter is.

Een andere factor die in aanmerking genomen moet worden is: de belasting-factor van de machine, dat is hoe lang de machine niet in gebruik is en of er dan ander werk voor gevonden kan worden. Kan b.v. een machine economisch gebruikt worden voor het opmaken van salaris-lijsten, dan zou de machine alleen b.v. aan het einde van iedere maand in gebruik zijn.

Het is dan wenschelijk dat voor de rest van de maand ander werk voor de machine gezocht wordt, ook al zou dit werk sneller met de hand gedaan kunnen worden. (Hiermede ben ik het volstrekt niet eens. L. P.)

\section{VOORDFELEN VAN DE BOEKHOUDMACHINE}

1e. Het aanpassingsvermogen van het systeem.

Gepunchte kaarten kunnen op verschillende manier'en gesorteerd worden en geven met geringe kosten en tijd allerlei gewenschte recapitulaties, die met de hand gemaakt, veel tijd zouden vereischen.

2e. De interne controle kan vaker worden toegepast doordat het opmaken van de saldi en tellingen sneller gaat en even tueele fouten worden daardoor gemakkelijker opgespoord. (Hiertegen is ook nog wel wat in te brengen). 3e. Door de snelheid van de machine kan b.v. een maandrapport veel eerler klaar zijn en heeft dus grooter waarde.

Het machinale systeen is het meest efficiënt voor groote bedrijven, waar veel gelijksoortige posten moeten worden ingeboekt, ved versehillende soorten posten zijn. De machine makt hierbij veel minder fouten.

Kleinere bedrijven die uiteraard veel minder posten hebben, zouden alleen een machine met voordeel kumnen gebruiken wanneer een geponste kaart vele malen gebruikt kon worden.

Grooter accuratesse.

De machine drukt de resultaten tegelijkertijd af, zoodat ze niet meer getypt behoeven te worden.

Bij handen-arbeid moet alle aanteekeningen gecontroleerd worden, bij machinale boekingen alleen de geponste kaarten.

\section{NADEELEN VAN DE BOEKHOUTMACHINES}

Zonder groote kosten kan een acenratesse van $98 \%$ bereikt worden. Voor Statistische doeleinden is dit voldoende, maar de bockhouding eischt $100 \%$ accuratesse en deze $2 \%$ is duur. Indien cen geponste kaart voor meerdere afdeelingen gebruikt wordt, kunnen die kosten omgeslagen worden.

Fen ander nadeel is het ontbreken van de omsehrijving bij de posten. Deze wordt angebracht, door coles, wat de duidelijkheid niet bevordert. (Dit bezwaar kan thans, door de schrijvende Powers-tabulator gedceltelijk worden ondervangen ).

Bij de inrichting van de machinale boekhouding wordt dikwijls tereel het oude systeem nagevolgd. De inrichting van de boekhouding met handen-arbeid is echter meestal niet geschikt voor de machinale en deze werkt dan niet op zijn voordeeligst of wordt. een aanhangsel van de andere. (Zeer juist).

De machines kummen wel cens defect raken, wat vooral voor afgelegen bedrijven, die niet spoedig een reparateur bij de hand hebben, groote bezwaren kunnen opleveren of in drukke tijden de gcheele administratie in de war sturen.

Bij groote drukte kumnen bij handen-arbeid meer bedienden aan het werk gezet worden; de machine kan echter niet meer werk verrichten.

In het bezit van machines heeft men de neiging het aantal rapporten en overzichten sterk uit te breiden, zonder dat er behoefte aan is en zoodanig dat de directie nict alles meer kan doorwerken.

13ij het aanschaffen van machines moct erop gelet worden: dat een plan gemaakt wordt waarvoor de machine nog meer gebruikt kan worden dan voor let doel waarvoor ze aangeschaft wordt. Ze kan dan ook gebruikt worden als ze in de betrokken afdeeling tijdelijk stilstaat. Een gevaar is echter dat ze dan voor onnoodige dingen gebruik wordt en de voornaamste over het hoofd worden gezien.

\section{BHSLUIT}

Interessante werking van de machine.

Ze ,lijken" te bezuinigen.

Aantrekkelijk voor machine-liefhebbers.

Lang niet in alle gevallen werkt de machine bezuinigend en vóór aanschaffing moet een grondig onderzıek hiernaar worden gedaan.

De kosten moeten vergeleken worden met de kosten wanneer hetzelffe werk met de hand gedaan wordr. Na installatie de kosten blijven controleeren en pas langzram aan het aantal uitbreiden. Bij het opmaken van de codes moct ook rekening gehouden worden met de toekomst.

Alleen wanneer met alle bovengenoemde factoren rekening wordt gehouden kan machinale arbeid voordeeliger zijn dan handen-arbeid.

L. P. 